\title{
THE DEPICTION OF SNAKE ORNAMENT ON GANESHA STATUE IN THE COLLECTION OF PRAMBANAN TEMPLE MUSEUM, YOGYAKARTA
}

\section{PENGGAMBARAN ORNAMEN ULAR PADA ARCA GANESHA KOLEKSI MUSEUM CANDI PRAMBANAN, YOGYAKARTA}

\author{
Ashar Murdihastomo \\ Pusat Penelitian Arkeologi Nasional \\ ashar.murdihastomo@kemdikbud.go.id
}

\begin{abstract}
ABSTRAK
Ganesha merupakan dewa terpopuler bagi umat Hindu setelah Trimurti. Dewa ini dipuja karena keberadaannya dapat memberikan kemakmuran dan menghindarkan segala rintangan dan marabahaya. Tidak mengherankan apabila dewa ini diarcakan dengan berbagai penggambaran. Salah satu penggambaran yang unik ditemukan di Museum Candi Prambanan, Yogyakarta. Ganesha digambarkan memiliki ornamen ular dan terdapat pahatan tikus sebagai wahananya. Tentunya gambaran ini belum pernah ditemukan di tempat lain sehingga diperlukan suatu kajian untuk mencari tahu cerita mitologi yang melekat dalam wujud tersebut. Selain itu, juga untuk menerka pemahaman masyarakat masa lalu terkait dengan penggambaran wujud tersebut dalam kehidupan sehari-hari. Kajian yang dilakukan ini menggunakan deskriptif-analisis dengan menggunakan kajian ikonografi sebagai dasarnya. Hasil yang diperoleh mengindikasikan bahwa arca Ganesha tersebut merupakan perwujudan dewa pelindung hasil panen.
\end{abstract}

Kata Kunci: Ganesha; Dewa Panen; Ular; Musika

\section{ABSTRACT}

Ganesha is the best-known deity after Trimurti in the Hindu pantheon. He is worshipped as the lord of beginnings and as the lord of removing obstacles. He is sculpted in various depictions. One of them, collected by the Prambanan Temple Museum, Yogyakarta, shows a snake and a mouse as his vahana (mount/vehicle). This image has never been found anywhere else. Therefore, this study was aimed to find out the mythological story behind that depiction and to investigate the past people's understanding of it. This descriptive study employed an iconographic analysis to analyze the collected data. The analysis results indicate that Ganesha is revered as the protector of crop yield (the harvest deity).

Keywords: Ganesha; Harvest Deity; Snake; Musika

$\begin{array}{ll}\text { Article Submitted } & : 10-11-2019 \\ \text { Article Accepted } & : 01-04-2020\end{array}$ 


\section{INTRODUCTION}

Deva, the term for a deity or god in Hinduism, is a manifestation of the invisible force that is considered to influence the events that occur in human life. This assumption places Devas as something that cannot be reached and humans make their hopes in daily life depends on them. This invisible aspect is realized in a certain form and is connected with certain mythologies related to the god figures. Their forms or manifestations are shaped like creatures in general but have differences. This is intended to show their character of godliness, positions, and superiority over other living things (Hadiyanta et al., 2014, p. 5).

The manifestation is in the form of a statue that is used as an object of worship. Endang Sri Hardiati (2010) argues that the statue is a depiction of a godly figure intended for worship activities. The depictions of deities in the form of statues in India are thought to have begun to emerge and were practiced during the Vedic period, although the use of this cult was only widespread during the Purana period. Scholars in the field of ancient Indian arts and culture believe that worship of the deity statues was influenced by Buddhists who worshiped and honored their spiritual leader by using a statue after the Buddha died (Rao, 1904 in Hardiati, 2010, p. 3). Hardiati also added that the making of a statue as a medium of worship could be related to the concept of devotional service which was an expression of the love and respect for the deities of the deities by his people. Usually, this statue is placed in a sacred building (temple). Hari Lelono (2013) states that in making statues has several requirements. Various conditions are needed considering statues as a worship media. The requirements include raw materials, iconographic and iconometric aspects, as well as the artists. The statue is made of raw rock (monolith) whose color is not stripped. The iconographic aspect is related to the physical description and certain characteristics as the identity of the character, while the iconometric aspect is related to the size and comparison of a statue related to its hierarchy. Artists are individuals who sculpt statues based on knowledge of iconography and iconometry as well as knowledge of rituals performed before the statues are carved. The four aspects are interrelated to one another to produce perfect work (Lelono, 2013, p. 95). The making of statues is also based on the existing rules, including those agreed upon and those explicitly determined by a religion (Asianto, 2015, p. 2). Such rules include the shape and ornamentation attached to the statue. These rules can also originate from mythological stories relating to the gods to be sculpted. This shows that every element that is attached to the statue is not something arbitrary.

One of the gods with a unique element attached to him and is very well known is Ganesha. He is a deity in Hinduism known as the son of Lord Shiva and Goddess Parvati. As one of Lord Shiva's family, it is not surprising that the statue of Ganesha is often found to be associated with Shiva-related relics, such as the lingga-yoni, Shiva statue, the statue of goddess Durga, and the statue of Resi Agastya. He is very easily recognized through his shape. This is because Ganesha has the form of half-human and half-animal, i.e. the head of an elephant atop a human body. Ganesha has special characteristics based on its iconographic aspects. Ratnaesih Maulana (1997, p. 104) mentions some of the attributes of Ganesha, including the presence of candrakapala decoration on the crown, third eye, and upawita snake. These three attributes indicate that Ganesha is one of Lord 
Shiva's family because they are also the attributes of Lord Shiva (Sedyawati, 1994, p. 65). Ganesha also has attributes that mark him. In the Agni Purana Book, the main attributes of Ganesha consist of aksamala, tusk, ax, and bowl. The four attributes are held by each arm, i.e. the front right arm holds the tusk and the back right arm the aksamala, while the front left arm holds the bowl, and the back left arm holds the ax (Maulana, 1997, p. 104).

Ganesha is a deity that is highly respected by Hindus. This is because his character is different from other gods. Ganesha is considered a god of obedience, worship, genius, protection, and good luck (Agarwal, 2018, p. 1; Dwyer, 2015, p. 7). He is labeled as a god of obedience because of the obedience he has towards his mother, goddess Parvati. The command given by his mother will not be denied by Ganesha and will be carried out even if it is obstructed by various obstacles (Agarwal, 2018, p. 1). Ganesha as a symbol of worship can be traced from the story of competition with her brother, Skanda or Kartikeya, to fight for one of the high positions in Kahyangan. Ganesha left the competition to worship his parents, Lord Shiva and Goddess Parvati. His devotion gave him a high position in Hinduism to become a god worshiped before Lord Shiva (Dwyer, 2015, p. 7). Ganesha is also one of the protectors of Hindus to avoid negative auras that try to distract the human mind. So, it is not surprising that the statue of Ganesha is often placed in locations that are often considered to be dangerous places, such as near rivers to help to cross or mitigate floods, crossroads, cliff edges, haunted places, under big trees, and places that are believed to be evil spirits (Rema, 2014, pp. 164-165). Besides, Ganesha is also worshiped by traders since he is considered capable of giving good influence to the buyers so that they are interested in the products and buy them (Nagar, 1992, p. 174).

Ganesha is also known as a god related to the harvest season as well as science and art. Ganesha as the harvest god is characterized by the presence of a mouse in his depiction. Rat or müşika as Ganesha's vahana is considered as an agricultural pest that often disturbs/steals crops that are about to harvest. Ganesha as the god of prosperity and remover of all forms of distress becomes a god who can subdue the animal and make it as its inheritance, so that Ganesha is also called Mūșaka Vāhana or "(the one) who rides agricultural pests" (Michael, 1983, p. 92). This is in line with (Kumaran, no year) who believes that the existence of the Ganesha statue is always associated with the abundance of crops and life. This is because Ganesha is an embodiment of Lord Shiva's mind which is manifested in five elements, i.e. earth, air, fire, water, and ether, which guide the forces of the elements that produce and maintain the order of the universe. Other information obtained from ancient Indian poetry equates spray of water that comes from its trunk with rainwater (Philadelphia Museum of Art, no year).

The popularity of Dewa Ganesha does not only occur in religious activities. In science, he has become one of the main objects of study. I Wayan Redig (1992) compared Ganesha in Indonesia and India. He concluded that the Ganesha statue has similar characteristics but his artistic style is influenced by each society. Edi Sedyawati (1994), in his dissertation, analyzed Ganesha statues during the period of the Kediri Kingdom to the Singhasari Kingdom. His study is considered as one of the main foundations in Indian iconography in Indonesia. The results of this 
study indicate that Ganesha statues in the era of Kediri and Singhasari are strongly influenced by the cultural conditions of the surrounding community.

Another uniqueness of the Ganesha statue is also discussed in the current study. Ganesha statue as the object of this study is the collection of the Prambanan Museum located in the northeast of Prambanan Temple Tourism Park. The uniqueness of the Ganesha statue is that there is a snake ornament attached to the crown on the back-right hand of Ganesha. This depiction is unique considering that no other Ganesha statue has such an ornament in Indonesia. Therefore, the problem statement in this study includes:

1. What is the relationship between the snake ornament on the Ganesha statue?

2. What is the purpose of depicting the snake ornament on the Ganesha statue?

From the two questions, this study seeks to investigate the role of a snake ornament on the Ganesha statue and the background of the depiction in the life of the ancient Javanese people.

In the discussion of worship statues, there are some important points of concern. Sedyawati argues that at least the elements of art and religion become the two main factors. The religion becomes the initial foundation considering this aspect is related to the rules that must be met in making statues. Religion is an inseparable part of organizing ideas and images of statues. Both of these are the result of understanding the characters, attitudes, and events that cause the god to have an image manifestation. Meanwhile, the artistic aspect tends to be the realization of the artist's creativity expressed following religious rules. This art aspect can then become one of the factors that can determine the development of statue art, such as Singhasari statue art and Majapahit statue art (Sedyawati, 1994, pp. 65-80).

Religion is the most dominant aspect of god sculpting. The religious aspect is indicated by a special form, decoration, special features (laksana), and other ornaments. Its existence is adjusted to the conditions of the surrounding community (Suantika, 2015, p. 116). This can be exemplified by the presence of Avatara statues of Vishnu in the Prambanan area in the form of Narasimha and Wamana which are often associated with the community's hope to be free from suffering. Another example, lord Shiva's statue is sometimes depicted in tiger skin clothing, which means he is a forest dweller. Some of these examples show that the different forms and ornaments are closely related to the myths and events experienced by the gods.

\section{METHODS}

This qualitative study used inductive reasoning with a descriptive-analytical method. The inductive reasoning was used to explain a problem with the existing data. While the descriptive-analytical method focuses on efforts to provide an overview or explanation of the object under study through the collected data and analysis to conclude (Sugiyono, 2009, p. 29). The basic approach employed iconography and iconology. Iconography is an analysis aiming to find out the 
identity of the statue by describing the iconographic features of the statue concerning the statue attributes as a depiction of a particular figure. Meanwhile, iconology is an analysis to find out the meaning of symbolic values attached to the figure of a statue. To find out the meaning, it is necessary to observe and compare iconographic features which are then interpreted with the supporting data from the mythology of the gods (National Archeology Research and Development Center, 2008, pp. 107-108).

Several steps were taken to answer the problem statements. The first step was to describe the statue in detail. This description used an iconographic approach that explained all the symbols in the statue, ranging from special features (laksana) and clothing (abharana). The description process was also guided by photo documentation to correct some things that were missed. The second step was to conduct a literature review by searching for written sources. The necessary information included the conception and role of Ganesha and snake in society. In addition, the literature review was also used to find stories to have a comprehensive view of the relationship between Ganesha and snake. The third step was to write a narrative on the results of data collection through both direct observation and literature review. The final step was to analyze and synthesize the results of the collected data to answer the problem statements.

\section{RESEARCH RESULTS}

\section{Description}

The Ganesha statue is sculpted in black monolith andesite stone with a height of $95 \mathrm{~cm}$, a width of $50 \mathrm{~cm}$, and a thickness of $50 \mathrm{~cm}$. This statue is located in the second exhibition building and is a collection of the Prambanan Museum (Figure 1) which is borrowed from the Central Java Cultural Heritage Preservation Center. This statue has no written registration number or museum inventory because it is only a loan collection. The condition of the statue is generally intact but there is damage in two areas, namely the back of the statue and on the face. The damage to the face removes some parts of the tusk attributes of the Ganesha, but the trunk structure can still be seen.

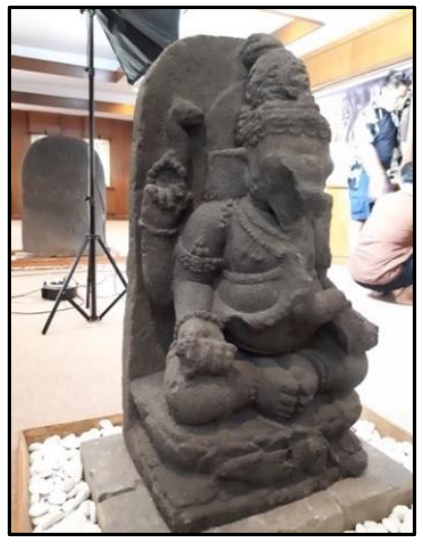

Figure 1. The snake-ornamented statue of Ganesha at Prambanan Temple Museum

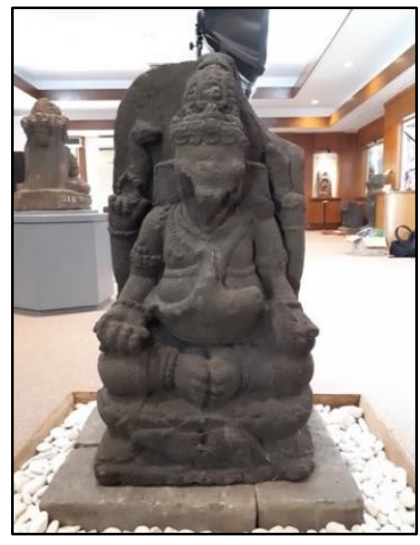

(Source: Ashar Murdihastomo)

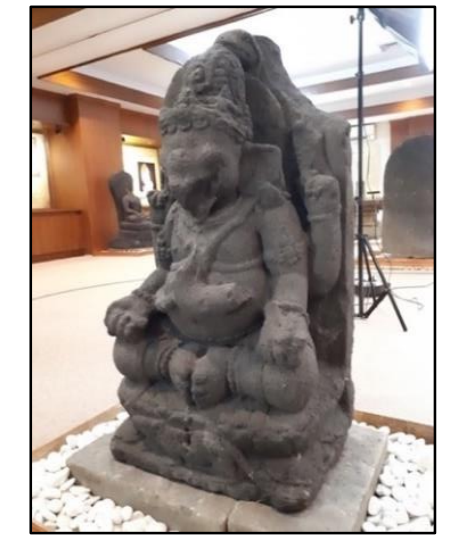

. 西 


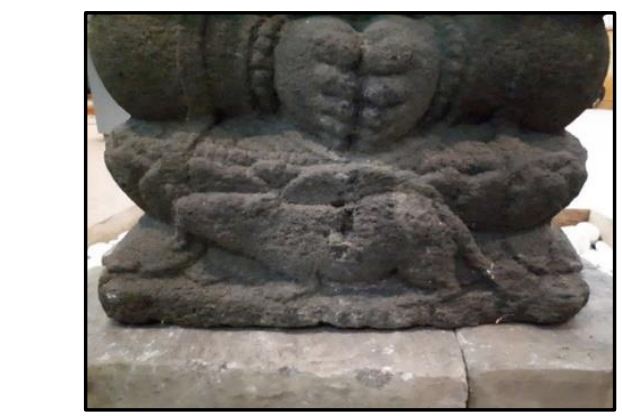

Figure 2. Ganesha's vahana in the form of a rat (Source: Ashar Murdihastomo)

The Ganesha statue is depicted as having a square-shaped backrest with the top having an oval shape. The statue is also depicted as having a layer or mat under a seat of the deity (āsana) which has a lotus flower decoration (padmāsana). The interesting thing about this part of the seat is the decoration in the form of a four-legged and one-tailed animal which is identified as a rat (Figure 2). The rat $(m \overline{u s s i k a})$ is a vahana or vehicle of Lord Ganesha so that the depiction of this animal shows that Ganesha is accompanied by his vahana.

In terms of the depiction of a figure, this Ganesha statue has an image that is commonly found in Indonesia. Ganesha is described as having four arms, a distended belly (tundila), and sitting with the posture of the soles of the feet (utkutikäsana). The head of the statue is described as having a circle of maturity (śiraścakra). Another characteristic is the clothes worn by the god. Ganesha is described as having a crown made from a tangle of elevated hair (jatāmakuta). On this crown, there is a skull ornament with a crescent moon at the bottom (ardhacandrākapāla). This crown decoration is then enhanced by the presence of frontlet at the base of the crown, which marks the boundary between the crown and the forehead. On the forehead, there is a thin scratch. This thin scratch is identified as the third eye (trinetra) considering that Ganesha is the son of Shiva who also has the same characteristics, one of which is having a third eye. In this part of the head, it is quite clear to see the shape of an elephant's head (the wide ears and a tusk) although it has been damaged. In addition, there are strands of hair dangling on the shoulder of the statue. This Ganesha body has an ornamental necklace (hâra) and a transverse chest belt (udarabandha). Another body decoration is the existence of a side ornament (upavita) in the form of a snake. On the arms, there are some decorations, including a curly ornament (keyüra) and a wristband (kankana). The lower body part of the statue is less clearly seen because of its crosslegged sitting position (uttutikasana), but other parts can still be clearly seen, including the cloth from the body to the ankles (antarvāsaka), a cloth shawl (uncal), and the anklets (pädasaras).

Ganesha also has a special characteristic that is well known among Hindus. The special features include the back-right arm holding the rosary (akșamala), the front right arm holding a tusk (ekadanta), the back-left hand holding an ax (paraśu), and the front left hand holding a bowl (modaka) to put the tip of the tusk. Another unique feature is the existence of two snake-shaped ornaments (Figure 3). The first snake ornament is behind the back-right arm. The snake has a head and body that 
is not too long. The head is depicted facing towards the left side or facing the head of Ganesha. The second snake ornament is above the crown of Ganesha. This snake is facing forward and rests on the crown of the Ganesha. The upper part of the snake's head has an upward bulge which can be identified as a small crown.
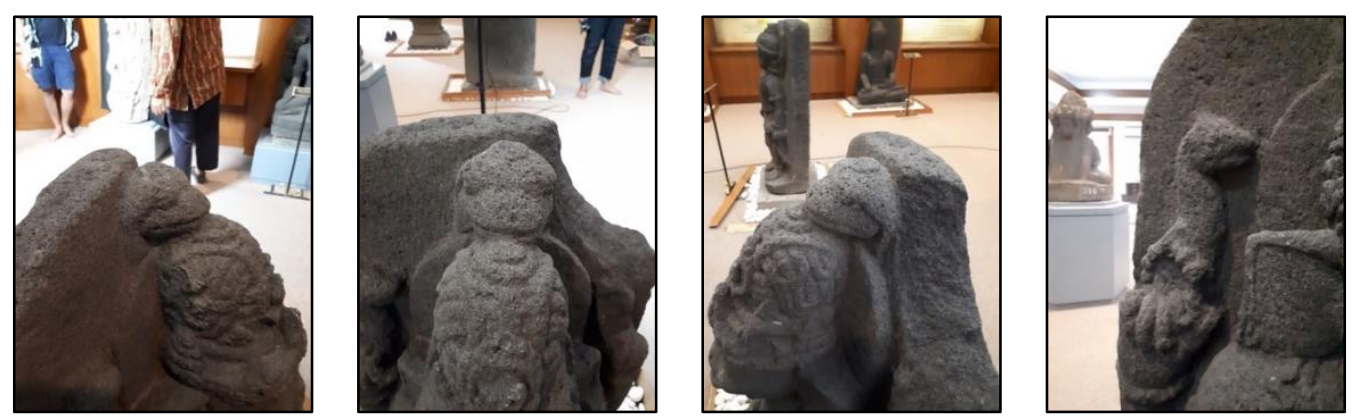

Figure 3. Serpent/snake ornament on Ganesha statue (Source: Ashar Murdihastomo)

\section{Worship of Ganesha and Snakes}

\section{Worship of Ganesha}

Ganesha is the son of Lord Shiva and Goddess Parvati who is more popular compared to Kartikeya. He is manifested as a mixture between a human and an animal, i.e. the head of an elephant atop a human body (Bagus, 2015, p. 25). Ganesha is one of the main companions of Lord Shiva in the Hindu Temples in Indonesia. The appearance of the head of an elephant in Ganesha is considered as a symbolic depiction of his mighty character (Suyasa, 2018, p. 8). Nyoman Rema said that the image is a manifestation of the relationship between microcosm and macrocosm. Rema also cites the opinion of Sedyawati who argues that the depiction of Ganesha is a manifestation of religious aspects that describe the characteristics of maturity, beyond humans, which distinguishes him from human form (Rema, 2014, p. 165).

The depiction of Ganesha is said to have two characteristics, namely general and special iconographic features. Adpoting from Sedyawati, I Wayan Suantika believes that general iconographic features of Ganesha Statue emphasize his identity in general while specific iconographic features are in the forms of signs based on mythological stories. Ganesha's common iconographic features are elephant-headed and human-bodied. Meanwhile, special iconographic features include tundila, trinetra, and ekadanta. Besides, there are also a upawita snake, ardhacandräkapāla decorations on the crown, and four arms (Suantika, 2015, p. 122).

The position of this god is very prominent and gets great attention from his worshipers who later developed into a separate sect, i.e. the Ganapatya sect. This sect is based on the abundant quantity of Ganesha statues (Suyasa, 2018, p. 4). The statues are found both in India and in Indonesia with a variety of sizes ranging from small, medium, to large. The Ganesha statue is also found in various positions, including sitting and standing as found in Palembang, Central Java, East Java, and Bali (Suantika, 2013, p. 44). 
The worship of Ganesha is so dominant because of his qualities. The main reason is that Ganesha is a god who is generous, loving, compassionate, and always helps people in achieving success and safety (Sumerata and Basudewa, 2016, p.99). Ganesha is also believed to have several characteristics, including the god of wisdom, the god of success, the deity of removing all obstacles, the god of science, medicine, and astrologer (Mansur, 2014, p. 115; Suantika, 2015, p. 126; Suyasa, 2018, pp. 7-8). In the Book of Koravāśrama, it is mentioned that the Ganesha became the main deity in the remover of bad luck. Another story states that Ganesha has a book about the gods' good and bad deeds that have been, are being, and will be done (Sumerata and Basudewa, 2016, p. 99).

These characteristics are indicated to appear in the depiction of the statue of Ganesha. The virtue characters are illustrated by the tip of the tusk that sucks the contents of the bowl (Suantika, 2015, p. 126). The tusk depiction is of two types, right and left. The tusk that extends to the left is called itambilambamburi, when it sticks out to the right so it is called walampiri or walamburi. The direction of the tusk indicates the direction the obstacle or bad luck appears. A fat body with a tundila belly is considered a symbol of well-being. The large ears indicate that Ganesha always listens to everything (Rema, 2014, p. 165).

Some of these are the reasons why Ganesha is very popular among Hindus. The popularity of Ganesha does not only belong to one sect because almost all sects worship Ganesha. This is because Ganesha is considered as a liaison with their main deity or also considered as opening the way to achieve the goals and success of the world (Brown, 1991, p. 1). This is in line with Brahmanda Purana Book which states that Ganesha must be worshiped first if humans want to get success in all endeavors (Sumerata and Basudewa, 2016, p. 99). For this reason, Ganesha does not only belong to one caste but also the other four castes, i.e. Brahmin, Kshatriya, Vaishya, and Shudra because he is deemed to be god of goodness (Michael, 1983, p. 91).

These qualities make Ganesha has several names. According to Hindu mythology, these names include Awighneswara or Wignantaka or Wighnakarta or Wighneswara. These names are interpreted as a remedy for danger. These names emerge from a mythological story about the battle between Ganesha and Nilarudaka who tried to attack Kahyangan. Ganesha's victory in the war against Nilarudaka made him known as the god of war (Suantika, 2013, p. 44). The victory also made Ganesha get blessings from Lord Brahma by giving him the name Siddhidata which means bringing success (Sumerata and Basudewa, 2016, p. 99). In the Book of Ganapati Tattwa, Ganesha is deemed as the protector of pests and plant diseases. The Book of Mahanirwana Tantra narrates that Ganesha is worshipped as a god of harvest and prosperity (Bagus, 2015, pp. 30-31). Furthermore, Ganesha also became a deity worshiped at the Gramadeśa level who guards, protects, and nurtures a village (Rema, 2014, p. 164).

Ganesha also has another name Winayaka which means to know everything. This name is found in the Book of Koravāśrama which mentions his qualities of being able to conduct all studies, understanding literary and religious books, having knowledge of the merits of a person, knowing the origin of the universe, knowing the age of others, being able to exchange voices, understanding the archery knowledge, knowing the time calculation, cannot be fooled, and others. 
The existence of these characteristics makes him a god of science that is juxtaposed with goddess Sarasvati. Ganesha represents masculine science, while the goddess Sarasvati represents feminine science (Bagus, 2015, p. 31). This makes him a god listed in the Sima Inscriptions as a witness written at the beginning or end of the inscription and part of the sapatha or curse. Some examples of the inscriptions include Gulung-Gulung inscription, Linggasuntan inscription, and Geweng inscription (all three were published by King Mpu Sindok between 929-930 AD), Wuatan Tija inscription dating to $880 \mathrm{AD}$ and Sugih Manek inscription dating to 915 AD (Bagus, 2015, p. 31), an ancient Balinese inscription named Sukawana AII which dates to 1054 AD (Bagus and Rema, 2017, pp. 70-71). Moreover, Ganesha is also known by several names such as Ganapati which means the leader of the Gana, Gajamukha or Gajanana which means to have an elephant's head, Ekadanta which means to have one tusk, Lambodara which means distended belly (Bagus, 2015, pp. 25-31; Geria, 2000, p. 127).

\section{Worship of the Snake}

Indian culture has a deep belief in a power beyond human capabilities. One of them is the belief in the power of nature which includes animal power. Some animals are considered to have magical powers that can affect human life. Therefore, humans worship animals.

Snake is one animal that is considered to have an influence on human life in Indian culture. Its existence is recorded in reliefs in the form of reliefs to statues. This decoration then spread to several areas affected by Indian culture. So, it is not surprising that this decoration can be found in the Indonesian archipelago, Southeast Asia, even China. Snakes are worshiped in several places based on their qualities. These characteristics include eyes that are always open, can appear and disappear quickly, can live in all conditions, and always change skin regularly that make them always look young (Bagus, 1993, pp. 55-56).

The qualities make the snake used as a particular symbol, i.e. the symbol of wisdom, soul and eternity, and fertility. A snake symbolizes wisdom because it is not closed his eyes throughout his life, so it is considered to see all events in nature. Not surprisingly, a snake is made a witness in a ceremonial ceremony. Snakes are a symbol of the soul because snakes can renew their skin so they always look young. This quality is in line with the atma which never dies and always experiences incarnation so it is considered as a symbol of eternity. A snake symbolizes fertility because, during the process of replacing the skin, fluid is deemed able to help fertility. In Indian tradition, water is a symbol of Lord Vishnu. The mythological story narrates that Lord Vishnu was transformed into the world into a snake along with goddess Sri (sometimes also referred to as Laksmi). In addition, a snake symbolizes something that can create rain (Bagus, 1993, pp. 5556).

Another type of mythological snake that is worshiped is the Dragon. In some mythological stories, Dragon has a different physical appearance from ordinary snakes. Dragons have a body image that is bigger than a snake, has legs, and has jewelry on its body (Santiko, 2015, p. 87). This dragon is worshiped throughout the Southeast Asian region. Its depiction is not always manifested in the form of animals but sometimes it is depicted as a human with a dragon decoration that 
covers the head (Geer, 2008, p. 37). The dragon decoration that appears in the Indonesian archipelago, especially on Hindu-Buddhist influences, is closely related to the story of searching for amerta water, namely Samudramanthana or Amrtamanthana (Santiko, 2015, p. 86). The Dragon has the same symbol as a snake which is considered as a symbol of soil fertility and to maintain the security and wealth of the land. Dragons are also a symbol of the power of life because they repeatedly replace the skin making it possible to live longer. In addition, they symbolize strength and fertility in the soil (Wahyudi and Jati, 2018, p. 187). The symbolization of the snake decoration can also be strengthened by archaeological remains in Indonesia, especially in sacred places. This decoration can be found in the form of jaladwara in some temples. Snakes are also decoration on Dwarapala statue, both being held with arms and serving as a transverse chest decoration (upavita) as found in Sewu Temple, Plaosan Temple, and Singhasari Temple. In addition, this ornament also appears in the sacred remains of petirtaan ${ }^{1}$ (Sarjanawati, 2010, pp. 162-167; Wahyudi and Jati, 2018, pp. 187-191).

\section{DISCUSSIONS}

\section{The Linkage between Ganesha and Snake Ornament}

Ganesha has a connection with snake ornaments. This relationship can be traced through the mythological stories. The first story is related to Ganesha's curse on the moon. This story begins with Ganesha eating a lot of candies until his belly became very big and hard to move. When he was going home, Ganesha rode a mouse as his vahana. In the journey, Ganesha was interrupted by a snake that surprised him and made him fell. Ganesha could not stand because his belly was full. Therefore, Ganesha tied his belly with a snake that had blocked his way. The fall of Ganesha was seen by the moon that it laughed out loud. Ganesha was offended by the moon and cursed him to disappear. The incident made the world dark so there are many requests to Ganesha to cancel the curse. Ganesha could not undo the curse but could change it so that the moon only disappears once a month (Dwyer, 2015, p. 270).

Next, the depiction of Ganesha dancing on the Kalinga snake (also known as Kaliya) (Figure 4) is often referred to as Kalinga Nartana Ganapati or Ganesha Nartana (Ayyayyu, 2016). Interestingly, this depiction is also found in Lord Krishna (Nikhil, 2016) (Figure 4). This depiction tells the Yamuna river which was inhabited by a poisonous snake named Kaliya. This snake brought havoc to the villagers around Yamuna. Krishna who was the reincarnation of Lord Vishnu succeeded in defeating and expelling the snake from that place. In another story, Ganesha is also called a form of Krishna's reincarnation. Therefore, it is very possible if this depiction can be found in two forms of gods, namely Krishna and Ganesha (Phillips, 1988, p. 122).

The two stories show that the relationship between Ganesha and snakes tends to lie in the aspect of Ganesha as the protector from danger. This character is derived from the Ganesha's courage in conquering the snake, as in the first story

${ }^{1}$ water shrine or water temple, also known as water castle 
it is said that Ganesha used a snake to bind his belly because it caused Ganesha to fall and it was difficult to get up and the second story about Ganesha making the dangerous Kaliya snake obey him by dancing on his head. The snake ornaments on the statue of Ganesha in the Prambanan Temple Museum have a different purpose of the depiction as seen from the pattern. The depiction of Ganesha in the first story shows that the snake is on the belly and the second story shows that Ganesha stands on the snake, while the snake ornament on the Ganesha statue at Prambanan Temple Museum is attached to the back-right arm and the crown.
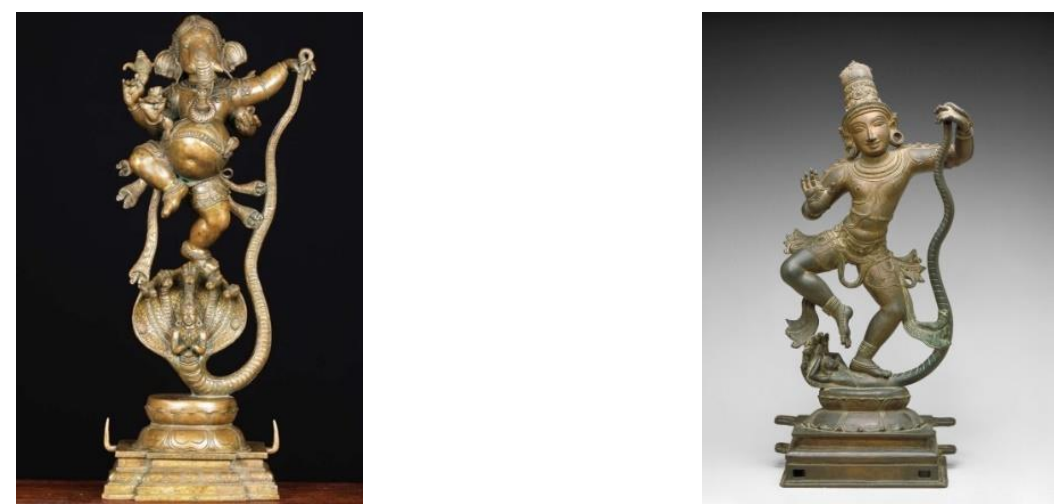

Figure 4. Comparison of the depictions of Ganesha Nartana and Krishna Nartana (Source: (a) Ayyayu; (b) Nikhil)

The linkage between Ganesha and snake ornaments is investigated through mythology and beliefs that are reflected in the context of the statue findings. Based on the mythology, the statue of Ganesha can be found in several types of places, including in the sacred building as one part of the pantheon of Lord Shiva's group, in a place indicated to be dangerous such as rivers and ravines, and in fields or areas related to agriculture. Examples of such statue placements include the Ganesha statue in Prambanan Temple as one part of the worship of a group of gods in the main temple, i.e. Shiva Temple. The Gebang Temple in Yogyakarta is thought to be a place of worship for Ganesha to provide protection and security from the nearby river (Figure 5) (Astuti, 2011, p. 28). The Ganesha Statue in Bali is sometimes found in the Subak area which is associated with the worship to ask for holy water for the surrounding area (Figure 6) (Rem a, 2014, p. 161).

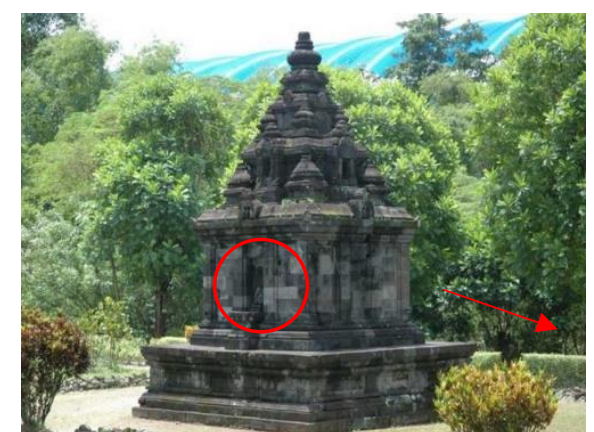

Figure 5. Gebang Temple, (circle) Ganesha Statue, (arrow) watershed (Source: jogjaempatroda.com, 2017)

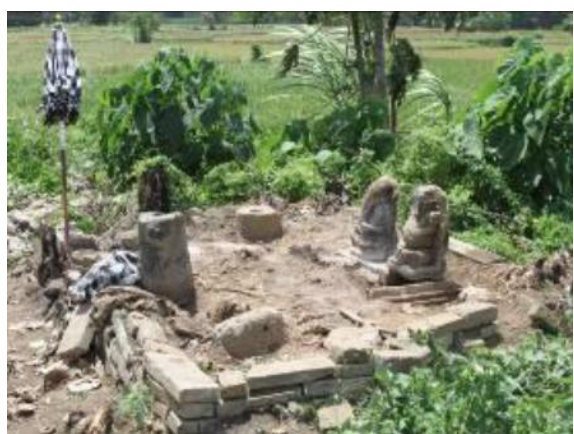

Figure 6. Statues in Subak area (Source: Archaeology Research Office of Bali, 2010 in Rema, 2014) 
Meanwhile, snake ornaments can be found in some archeological remains of the Hindu-Buddhist period. The ornaments are dominated by findings that have a context with holy water, known as Amerta. Some examples of these findings include dragon ornaments in linga and yoni, snake ornaments on Petirtaan Jalatunda, and snake ornaments on Goddess Sri's shower statue in Sarangan. The statue ornament in linga and yoni is one of the art elements found in the VIII-X century AD. Some linga and yonis with these ornaments are located at Tanjungtirta, Prambanan (Central Java Cultural Heritage Preservation Center/BPCB, 2016); Sambisari Temple (National Library, no year); and Ijo Temple (Sartono, 2016) (Figure 7).

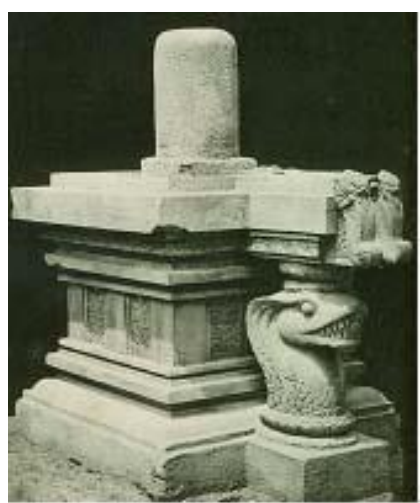

(a)

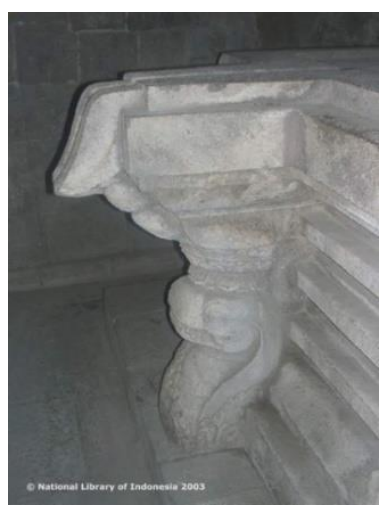

(b)

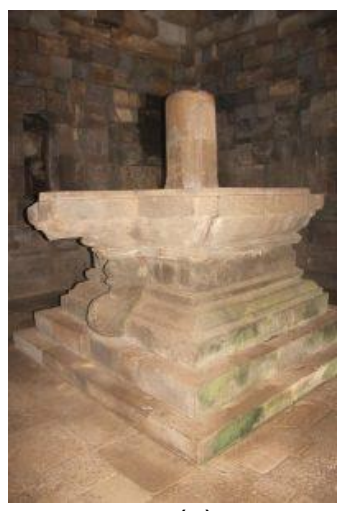

(c)

Figure 7. Dragon ornaments on Lingga-Yoni: (a) Tanjungtirto,

(b) Sambisari Temple, (c) ljo Temple

(Source: (a) BPCB of Central Java, 2016; (b) National Library, no year,

(c) Sartono, 2016)

The existence of this ornamentation is increasingly visible when the great Hindu-Buddhist civilization began to develop in East Java. The context of the findings that are still visible today is not much different from the previous findings, i.e. water. A study conducted by Santiko (2015, pp. 88-89) shows some archaeological objects in East Java have snake ornaments in Jalatunda Temple (Figure 8), Naga Temple in Penataran Temple complex, and Kidal Temple. In addition, a snake ornament is also found in the Sarangan area on the slopes of Mount Lawu (Figure 9) (Winaya, 2016, p. 33).

Life survival is a visible aspect in the depiction of Ganesha and snake in the lives of past peoples. Paddy fields are places to grow crops that support their lives. Water is the main supporter because it can make crops in the fields grow. This also indicates an agrarian life at the time of the development of ancient kingdoms in Indonesia. The agrarian life can be found from farming activities whose evidence can be obtained from several archaeological remains, such as relief of paddy fields at Borobudur Temple, waiting for harvest time, plowing the fields, and bearing paddy yields (Nastiti, 2016, pp. 266-268). There are also the taxes imposed on the people, one of which is a tax from agriculture (Nastiti, 2016, pp. 45-47). Moreover, there are also some names of royal officials who take care of agricultural activities, including pulung padi (paddy tax collector), pangalasan (forestry officer), 
patangkalan (enumerator of important crops), hulu wras (officials who take care of the harvest), and huluair (officials who oversee the waters) (Nastiti, 2016, p. 27).

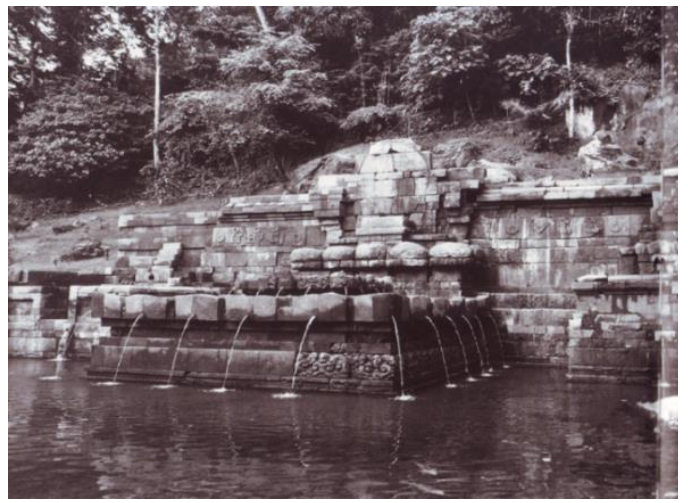

Figure 8. Petirtaan/ Water Temple Jalatunda (Source: Hariani Santiko, 2015)

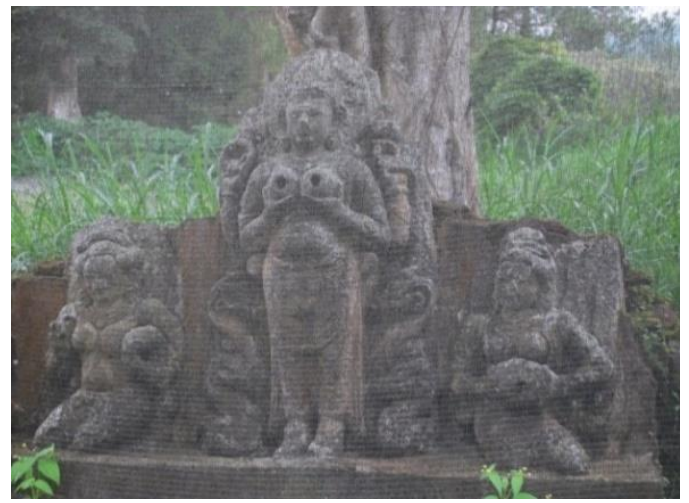

Figure 9. Snake ornament on Goddess Sri's fountain sculpture in Sarangan (Source: Atina Winaya, 2016)

The effort to protect food crops through worshiping Ganesha is in line with Michael's study which focuses on the depiction of a rat that becomes his feature. The rat is deemed a crop pest that can be subdued by Ganesha. The rat ornament is also found in the Ganesha statue at Prambanan Temple Museum, which is attached to the padmasana. Michael's study also reveals that as a harvest god, sometimes the Ganesha statue is completed with a snake ornament attached to his crown, which is also found in the Ganesha statue at Prambanan Temple Museum (Michael, 1983, p. 92).

\section{CONCLUSIONS}

Ganesha is a god Hinduism who has an important position in ancient people's lives. He is worshiped as the remover of unkindness and the giver of goodness. Inevitably, the depiction of Ganesha in the form of statues is often found in different areas, including places of worship, dangerous places, and places that are considered important for people's lives.

The important role of Ganesha in people's lives can be indicated from the depiction of him. The statue collection of the Prambanan Temple Museum is an example of a depiction of Ganesha that shows such a role through the presence of an additional ornament, i.e. the snake. Based on the iconology analysis and its context, the snake is a representation of fertility. Concerning Ganesha as the god of prosperity, the snake can be interpreted as the protector of crops which are an essential part of the lives of the people in the past.

This depiction model shows that people's lives can influence the form of depictions of a statue. The results of this study are also in line with the study conducted by Edi Sedyawati in her dissertation related to the depiction of statues in the lives of the people of Kediri and Singhasari Kingdoms. This study also suggests that such a depiction pattern has existed since the days of the Ancient Mataram Kingdom. 


\section{BIBLIOGRAPHY}

Agarwal, R. (2018). Ganesa in the Hindu Pantheon. In M. Jain, Pankaj; Sherma, Rita D; Khanna (Ed.), Hinduism and Tribal Religions, Encyclopedia of Indian Religions (pp. 1-2). Dordrecht: Springer Netherlands.

Art, P. M. of. (n.d.). Dancing Ganesha. Retrieved February 25, 2020, from https://www.philamuseum.org/doc_downloads/education/object_resour ces/66543.pdf.

Asianto, D. R. (2015). Karakteristik Arca Pada Kompleks Percandian Dieng. Universitas Gadjah Mada.

Astuti, W. (2011). Candi Kimpulan: Kecil dengan Arsitektur Unik dan Langka. Buletin Narasimha, pp. 23-30.

Ayyayyu, A. S. (2016). Legacy of Wisdom. Retrieved February 18, 2020, from legacyofwisdom website: https://www.philamuseum.org/doc_downloads/education/object_resour ces/66543.pdf.

Bagus, A.A. Gde dan Rema, N. (2017). Keharmonisan dalam Tinggalan Arkeologi di Pura Dangka, Tembau, Denpasar. Forum Arkeologi, 30(2), pp. 63-76.

Bagus, A. A. G. (1993). Makna Hiasan Ular Pada Arca Siwa Bhairawa di Pura Kebo Edan, Pejeng. Forum Arkeologi, 6(1), pp. 54-63.

Bagus, A. A. G. (2015). Arca Ganesa Bertangan Delapan Belas di Pura Pingit Melamba Bunutin, Kintamani, Bangli. Forum Arkeologi, 28(1), pp. 25-34.

Brown, R. L. (Ed.). (1991). Ganesh: Studies of an Asian God. New York: University of New York.

Dwyer, R. (2015). Vighaharta Shri Siddhivinayak: Ganesh, Remover of Obstacles, Lord of Beginnings in Mumbai. Comparative Studies of South Asia, Africa, and the Middle East, 35(2), pp. 263-276.

Geer, A. van der. (2008). Animals in Stone: Indian Mammals Sculptured Through Time. Leiden: Koninklijke Brill NV.

Geria, I. M. (2000). Sekte Ganapati Implementasinya dalam Budaya Bali. Forum Arkeologi, (2), pp. 125-134.

Hadiyanta, Eka; Romawati, Sri Muryantini; Tanzaq, Y. (2014). Dalam E. Astuti, Wahyu; Hadiyanta (Ed.), Katalog Koleksi Arca Batu. Yogyakarta: Balai Pelestarian Cagar Budaya Yogyakarta. 
Hardiati, E. S. (2010). Aspects of Indonesian Archaeology No. 28: Hindu-Buddhist Iconography in Sumatra. Jakarta: Pusat Penelitian dan Pengembangan Arkeologi Nasional.

Kumaran, T. S. (n.d.). Ganesha. Retrieved March 11, 2020, from cincinnatitemple.com website: http://cincinnatitemple.com/wpcontent/uploads/images/pdf/Ganesha-e-Book.pdf.

Lelono, T. M. H. (2013). Bahan dan Cara Pembuatan Arca Batu sebagai Komponen Penting Candi-Candi Masa Klasik di Jawa. Berkala Arkeologi, 33(1), pp. 93-108.

Mansur, M. (2014). Pengaruh Hindu pada Beberapa Wilayah di Jawa Barat melalui Arca-Arca Koleksi Museum Sribaduga. Etnohistori, 1(2), pp. 112-120.

Maulana, R. (1997). Ikonografi Hindu. Jakarta: Fakultas Sastra Universitas Indonesia.

Michael, S. M. (1983). The Origin of the Ganapati Cult. Asian Folklore Studies, 42, pp. 91-116.

Nagar, S. L. (1992). The Cult of Vinayaka. New Delhi: Intellectual Publishing House.

Nasional, P. (n.d.). Candi Sambisari. Retrieved March 13, 2020, from candi.perpusnas.go.id website: https://candi.perpusnas.go.id/temples/deskripsi-yogyakartacandi_sambisari

Nasional, P. P. dan P. A. (2008). Metode Penelitian Arkeologi. Jakarta: Pusat Penelitian dan Pengembangan Arkeologi Nasional.

Nastiti, T. S. (2016). Perempuan Jawa: Kedudukan dan Perannya dalam Masyarakat Abad VIII-XV. Bandung: Pustaka Jaya.

Nikhil. (2016). Kalinga Narthana Thillana: An Experiment in Rhythm and Language.

Phillips, K. J. (1988). Hindu Avatars, Moslem Martyrs, and Primitive Dying Gods in E.M. Forster's: A Passage to India. Journal of Modern Literature, 15(1), pp. 120-140.

Redig, I. W. (1992). A Comparative Study of Ganesa Images from India and Indonesia (From Circa 7th to 15th Century A.D.). Panjab University.

Rema, N. (2014). Arca Ganesa dalam Sikap Swastikasana. Sangkhakala, 17(2), pp. $55-168$. 
Santiko, H. (2015). Ragam Hias Ular-Naga di tempat Sakral Periode Jawa Timur. Amerta, 33(2), pp. 77-134.

Sarjanawati, R. S. W. (2010). Arca Dwarapala pada Candi-Candi Buddha di Jawa Tengah. Paramita, 20(2), pp. 158-168.

Sartono, A. (2016). Kompleks Candi Ijo Punya 11 Teras. Retrieved March 13, 2020, from tembi.net website: https://www.tembi.net/2016/11/15/komplekscandi-ijo-punya-11-teras/

Sedyawati, E. (1994). Pengarcaan Gaņeśa Masa Kadiri dan Sighasāri: Sebuah Tinjauan Sejarah Kesenian. Jakarta: LIPI-Rul.

Suantika, I. W. (2013). Arca Garuda Wisnu di Pura Gelang Agung, Buangga, Getasan, Petang, Badung. Forum Arkeologi, 26(1), pp. 38-51.

Suantika, I. W. (2015). Tinggalan Arkeologi di Pura Puseh Kiadan, Kecamatan Petang, Kabupaten Badung, Kajian Bentuk dan Fungsi. Forum Arkeologi, 28(2), pp. 115-130.

Sugiyono. (2009). Metode Penelitian Kuantitatif, Kualitatif, dan RED. Bandung: Alfabeta.

Sumerata, I Wayan dan Basudewa, G. Y. (2016). Arca Bercorak Siwaistis di Kota Denpasar, Bali. Forum Arkeologi, 29(2), pp. 93-104.

Suyasa, I. W. (2018). Arca Ganesa Tinggi Besar dengan Sikap Berdiri Tegak di Depan Pura Agung Jagatnatha Buleleng dalam Perspektif Kekinian. Widyasastra, 1(2), pp. 1-18.

Tengah, B. J. (2016). Lingga-Yoni. Retrieved March 13, 2020, from kebudayaan.kemdikbud.go.id website: https://kebudayaan.kemdikbud.go.id/bpcbjateng/lingga-yoni/.

Wahyudi, Deny Yudo, dan Jati, S. S. P. (2018). Arca Dwarapala Raksasa Gaya Seni Kadiri, Singhasari, dan Majapahit. Sejarah Dan Budaya, 12(2), pp. 180-193.

Winaya, A. et al. (2016). Penelitian Peradaban Mataram Kuna di Jawa Timur (Abad ke10 - 11 Masehi) di Kabupaten Magetan, Provinsi Jawa Timur. Jakarta. 